\title{
Morphological units in the Arabic mental lexicon
}

\author{
Sami Boudelaa*, William D. Marslen-Wilson \\ MRC Cognition and Brain Sciences Unit, 15 Chaucer Road, Cambridge CB2 2EF, UK
}

Received 5 September 2000; accepted 14 February 2001

\begin{abstract}
Standard views of morphology in Modern Standard Arabic hold that surface word forms comprise at least two morphemes: a three-consonantal root conveying semantic meaning and a word pattern carrying syntactic information. An alternative account claims that semantic information is carried by a bi-consonantal morphological unit called the etymon. Accordingly, in the form [batara] the core meaning is carried not by the tri-consonantal root morpheme $\{b t r\}$ but by the etymon morpheme $\{b, t\}$ which surfaces in other forms like [batta] "sever", [batala] "cut off" with the same meaning "cutting". Previous experimental research in Semitic languages has assumed the tri-consonantal root/word pattern approach. In cross-modal and masked priming experiments we ask whether the etymon, as a more fine-grained two-consonantal morphological unit, can yield the morphological priming effects typically obtained with tri-consonantal root morphemes. The results clearly show that two words sharing an etymon do facilitate each other both in cross-modal and masked priming even though they do not share a root, controlling for semantic and for form overlap effects. The bearing of these results on theories of morphological processing and representation is discussed. (C) 2001 Elsevier Science B.V. All rights reserved.
\end{abstract}

Keywords: Arabic morphology; Etymon; Root morpheme; Cross-modal priming; Masked priming

\section{Introduction}

Morphology, the study of the internal structure of lexical elements, has become an increasingly salient aspect of psycholinguistic research, focussing around the issue of whether the unit underlying lexical access and representation is the phonetic word or the morpheme (Marslen-Wilson, Tyler, Waksler, \& Older, 1994; Spencer \& Zwicky, 1998; Taft, 1994). Most of what we know about morphological processing and representation, however, relates to a few Indo-European languages, particularly

* Corresponding author. Fax: +44-1223-359062.

E-mail address: sami.boudelaa@mrc-cbu.cam.ac.uk (S. Boudelaa).

0010-0277/01/\$ - see front matter (C) 2001 Elsevier Science B.V. All rights reserved.

PII: S0010-0277(01)00119-6 
English. In languages of this type, morphologically complex items are typically formed by concatenating morphemic units in a linear manner, with the consequence that morphologically related words - as in the English "card/cards, friendlfriendly" - are normally also semantically, phonologically, and orthographically related. This leads to potential problems in empirically dissociating morphological effects from other sources of relationships between words.

One way of resolving these problems is by examining the role of morphology in language families whose morphological systems render this potential confounding less severe. A particularly fruitful opportunity is provided by Semitic languages, such as Arabic and Hebrew, which employ non-concatenative word formation processes. These are processes in which morphemic units are not linearly strung one after the other but are superimposed upon each other, such that every surface form is necessarily morphologically complex and its component morphemes are discontinuous. This feature, compounded by the richness and the explicit nature of Semitic morphology, makes such languages a suitable terrain to investigate genuine morphological effects. Indeed, Semitic languages, in particular Hebrew, have provided some of the most compelling evidence so far in favour of a morphemic lexicon (e.g. Frost, Forster, \& Deutsch, 1997).

In the present study we build on this cross-linguistic approach and address the question of morphological processing and representation from the perspective of Modern Standard Arabic (MSA), a Semitic language common to all literate speakers in the Arab world and used in the media, literature and all formal settings (Ferguson, 1959; Holes, 1995; Versteegh, 1997). The fundamental question we raise here is not so much whether the mental lexicon of MSA speakers is morphologically structured as whether the three-consonantal root is the correct basic unit underlying lexical processing and representation in MSA.

\subsection{Theories of Arabic morphology}

On the earliest philology-based accounts of Arabic morphology, a three-consonantal root and a word pattern are the two morphological units governing the structure of the language (Holes, 1995; Versteegh, 1997). Thus, an item like [naqala] "move" is a surface form analyzed as comprising a root morpheme $\{\mathrm{nql}\}$ and a pattern $\{$ faSala\}, where the generic consonants /f,, , $1 /$ indicate the slots into which the first, second and third consonants of the actual root are inserted, given the pattern of vowels and consonants specified by the word pattern. The preponderance of productive paradigms like [naqala] "move", [naaqilun] "one who moves", [nuqlatun] "a move", [nuqila] "be moved" in which all the surface forms share three consonants and exhibit a strong semantic overlap is cited as evidence in favour of the root. Equally, the existence of forms such as [naaqilun] "one who moves", [qaatilun] "one who kills", [kaatibun] "one who writes" etc., which share the active participle pattern \{faafilun\}, speaks in favour of the word pattern being an organizational unit of the language. However, despite the long-standing success of this early analytic model, it is arguably flawed in at least two fundamental respects.

The first fundamental problem for this view is that it is unable to capture the 


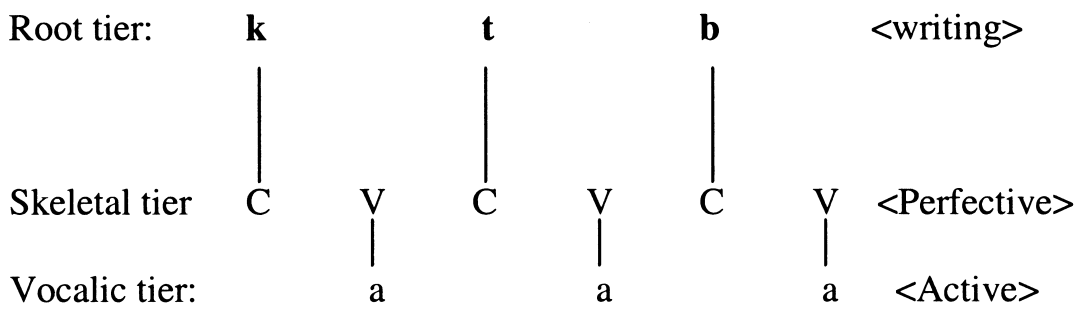

Fig. 1. Multilinear prosodic representation of the surface form [kataba] "write".

relationship underlying derived word forms like [naqala] "move", [nuqila] "be moved" or [haazama] "attack", [huuzima] "be attacked". All it can say is that the first two word forms are two distinct realizations of the root $\{$ nql $\}$, and the second two are different realizations of the root $\left\{\mathrm{h}_{3} \mathrm{~m}\right\}$. As for the word patterns, it has to assume the existence of four independent patterns, namely $\{$ faSala\}, \{fuSila $\},\{$ faafala $\}$ and $\{$ fuufila $\}$. It is clear, however, that each active-passive pair illustrates the same alternation in the internal vowel sequence with "a-a" in the active and " $\mathrm{u}-\mathrm{i}$ " in the passive and that it is only this alternation in vowel sequence that underlies the active-passive opposition. It is on the basis of arguments such as this that McCarthy $(1979,1981)$, working within the framework of autosegmental phonology (Goldsmith, 1976), suggested an analysis of Arabic surface word forms as comprising three morphemes. The first is the root morpheme consisting of three consonants which convey semantic meaning, the second is the vocalic morpheme consisting of vowels which contain syntactic information and the third is the skeleton which is a canonical template of consonant-vowel sequences conveying information about the timing units of the word. Thus, the surface form [naqala] is claimed to comprise the root morpheme $\{\mathrm{nql}\}$, the vocalic morpheme $\{a-a\}$ and the skeletal morpheme $\{C V C V C\}$ and its representation is shown in Fig. 1.

The second flaw in the root and pattern account of Arabic lies in its inability to capture the relationship between forms such as [batta] "cut off", [batara] "sever", [balata] "sever", [bataka] "separate", [sabata] "cut down". These words share only two consonants $(/ \mathrm{t} / \mathrm{and} / \mathrm{b} /)$ and would normally be classed as being based on five different roots $(\{b t t\},\{b t r\},\{b l t\},\{b t k\},\{s b t\})$, even though they exhibit the phonological and semantic overlap typical of surface forms sharing a single root morpheme. Bohas (1997, 1999) argues on the basis of such commonly occurring paradigms that the use of three-consonantal root as the lowest level unit fails to capture substantial regularities in the Arabic lexicon. To remedy this, he suggests a bi-consonantal unit called the etymon as the cornerstone of Arabic morphology. On this account, which echoes to a large extent the work of medieval Arab lexicographers, ${ }^{1}$ the words [batara] "sever" and [sabata] "cut down" underlyingly share the etymon morpheme

\footnotetext{
${ }^{1}$ See Versteegh (1997) for a discussion of the similarities between the etymon approach and the medieval Arab lexicographer Ibn Jinni's approach.
} 
$\{b, t\}$, the vocalic morpheme $\{a-a\}$ and the skeleton $\{\mathrm{CVCVC}\}$. In order to have a surface form the bi-consonantal etymon morpheme is morphologically expanded by the addition of an epenthetic segment (i.e. a segment inserted as a result of a phonological process) specified as non-syllabic, which covers the 27 consonants of the language. Thus, the epenthetic segment is $/ \mathrm{r} /$ in [barata] and $/ \mathrm{s} /$ in [sabata].

The etymon approach accounts for allomorphic variation in MSA in a natural way. Allomorphic variation refers to cases where the same morpheme surfaces in different phonetic shapes (Lieber, 1982). One instance of allomorphy, which the etymon approach deals with in MSA, is "etymon reversibility". For example, the etymon $\{\mathrm{t}, \mathrm{m}\}$ surfaces with the consonant $/ \mathrm{m} /$ before $/ \mathrm{t} /$ in the form [maata] "perish", but with the reverse order in the form [tamma] "come to an end" without changing the core meaning of the etymon. Of the possible 325 etymons in Arabic, 135 are analogous to the etymon $\{\mathrm{t}, \mathrm{m}\}$ surfacing with their two consonants in either order without changing the meaning (Bohas \& Darfouf, 1993). A second instance of allomorphy is in cases where the segmental structure of the surface form is different across the realizations of a family of related forms, argued to be linked back to the same underlying etymon morpheme. An example is the set of forms [\$ٔsabara] "bind", [d्dabba] "keep under lock", [rabat'a] "tie up", [Yaqada] "knot", [habasa] "hold back", [habaka] "bind", [hablun] "a rope", [Yaffa] "refrain", where the etymon consonants are in bold, and where they all share a core meaning related to notions such as "restraint" and "tying up". The underlying phonological commonality between these forms is that they all consist of a featural combination of a [+labial] consonant and a $[+$ pharyngeal or + pharyngealized $]$ consonant, suggesting that the abstract specification of the form of the etymon is in featural rather than segmental terms.

From a descriptive perspective, etymon identification proceeds in much the same way as that of the classical root, relying on systematic form and meaning overlap between surface word forms. Thus, in the forms [sabata] "cut down", [batara] "cut off" the etymon is $\{b, t\}$ rather than $\{\mathrm{s}, \mathrm{t}\}$ or $\{\mathrm{b}, \mathrm{r}\}$, because the meaning "cutting" recurs in other forms containing the two consonants $/ \mathrm{b}, \mathrm{t} /$ as in [tabba] "cut" and because this is consistent with the featural specification of the etymon as [+labial] and $\left[+\right.$ dental]. By the same token, the forms [ $\mathrm{s}^{\mathrm{f}} \mathrm{abara}$ ] "tie" and [rabat'a] "bind" are morphologically related because they share the consonant $/ \mathrm{b} /$ and their respective $/ \mathrm{s} /$ and $/ t^{\mathrm{s}} /$ consonants are homorganic in that that they are both pharyngealized.

There are cases where two surface forms like [?iqtifaa?un]/[tawfiiqun] "tracking"/"success" are considered to be morphologically related despite their semantic opacity. The verdict that such surface forms are morphologically related hinges on the fact that they are part of a larger set of words that are phonologically and semantically related. Thus, the meaning "tracking", which is absent from the surface form [tawfiiqun] "success", does emerge in the expressions [wifqan + li] and [wifaaqan + li] "in pursuance of", which are other instantiations of the etymon $\{f, q\}$ using the epenthetic consonant $/ \mathrm{w} /$ as is the case of [tawfiiqun]. In other words, the fact that the meaning of "tracking" or "pursuance" is not apparent in the etymon $\{\mathrm{f}, \mathrm{q}\}$ when expanded with the consonant $/ \mathrm{w} /$ in the surface form [tawfiiqun] does not preclude this meaning from emerging in other surface forms using the same consonantal material. 


\subsection{Previous research}

Research into the effects of morphological units on language processing and representation in non-concatenative morphology languages owes a great deal to Frost, Deutsch, Forster and their collaborators, who have focussed on Hebrew morphology. For example, on the basis of a series of masked priming experiments, Frost et al. (1997) found that the three-consonantal root governs lexical retrieval in nouns, whereas the word pattern morpheme does not. In verb morphology, however, Deutsch, Frost, and Forster (1998) have obtained facilitation effects in lexical decisions and in naming when the targets and the primes shared either a word pattern or root morpheme in verb morphology. Using cross-modal priming, Frost, Deutsch, Gilboa, Tannenbaum, and Marslen-Wilson (in press) were able to show that morphological priming in Hebrew cannot be reduced either to semantic or phonological overlap. The strong sensitivity of Hebrew speakers to tri-consonantal morphemes during online language processing is also documented in several other studies (Bentin \& Feldman, 1990; Feldman \& Bentin, 1994; Feldman, Frost, $\&$ Pnini, 1995). In a different area, Barakai (1980) reports the case of an aphasic Hebrew speaker who makes errors on word patterns but not on root consonants, while there is also a report of an Arabic speaking dyslexic whose processing of root consonants is selectively impaired while his behaviour with word patterns is normal (Mimouni, Béland, Danault, \& Idrissi, 1995; Prunet, Béland, \& Idrissi, 1998, in press). Further support for the three-consonantal root stems from Arabic speech errors which are insensitive to a syllabic positional constraint. The syllabic positional constraint refers to the fact that erroneous speech usually involves segments belonging to similar syllabic constituents such that onsets are substituted for onsets and codas for codas. Unlike erroneous speech in Indo-European languages, Arabic speech errors involve segments belonging to different syllabic constituents with onset consonants and coda consonants swapping positions (e.g. [rurfa] produced instead of [yurfa] "room"). This happens only if the consonants involved in the error belong to the same root morphemes (Abd-Al-Jawad \& Abu-Salim, 1987; Berg \& Abd-El-Jawad, 1996).

Thus far the theoretical background of all the research into Semitic morphology is the root and word pattern approach, which seems to fit quite well with the experimental data obtained both from normal subjects and patients. We argue here that such an account may be replaced by an analysis built around the concept of the etymon, and that the root morpheme effects reported in the literature may reflect, at least in part, the operation of a more fine-grained unit: the etymon. To establish the etymon morpheme as a psychologically valid unit, we assess whether pairs of primes and targets sharing an etymon morpheme but not a root morpheme yield priming effects comparable to those already well-documented for prime-target pairs sharing a root morpheme.

\subsection{Experimental issues}

To test the extent to which the etymon morpheme can act as a lexical unit the 
present study uses two experimental paradigms: cross-modal immediate repetition priming and masked morphological priming. Typically, in cross-modal priming the visual display of a target probe is made to coincide with the acoustic offset of an auditory prime. Participants have to make a lexical decision to the visual target. The advantage of this paradigm is that it picks up genuine morphological effects and is relatively less prone to the episodic effects potentially seen in delayed repetition priming. Since prime and target are in different modalities, we assume that participants are led to answer at a supra-modal level where modality-independent information, such as semantic, syntactic and abstract phonological-featural attributes of words, is available (Marslen-Wilson, 1999; Marslen-Wilson et al., 1994; MarslenWilson \& Zhou, 1999; Marslen-Wilson, Zhou, \& Ford, 1996). This level is the appropriate locus at which to track processes of morphological parsing.

The second paradigm we utilize, masked priming, consists of a forward pattern mask, a prime word presented for a very brief duration - $48 \mathrm{~ms}$ or less - and a target word serving as a backward mask of the prime (Forster, 1999; Forster, Davis, Schoknecht, \& Carter, 1987; Forster \& Taft, 1994). The forward and backward masks along with the very brief display of the prime are assumed to rule out both the possibility of any episodic trace of the prime being created and the instantiation of any strategic components of processing. One difference between cross-modal and masked priming is that while participants are aware of the prime in the cross-modal paradigm they are unaware of it in masked priming. Another difference is that crossmodal priming is relatively insensitive to form overlap between prime and target (Marslen-Wilson et al., 1994) while masked priming is not (Forster et al., 1987). A third difference consists of the sensitivity of cross-modal priming to semantic factors whilst masked semantic priming effects are unstable and weak (Sereno, 1991).

The two paradigms have been extensively used to study the use of morphological structure during lexical processing in a few languages. For example, masked morphological priming effects were obtained in German (Drews \& Zwitserlood, 1995), Hebrew (Frost et al., 1997), and English (Marslen-Wilson et al., 1996; Rastle, Davis, Marslen-Wilson, \& Tyler, 2000). Equally, cross-modal morphological effects were obtained in English (Marslen-Wilson et al., 1994), Italian (Orsolini \& MarslenWilson, 1997), French (Meunier \& Segui, 1999), and Hebrew (Frost et al., 1997). The two paradigms complement each other and as such will allow us to sharply focus on the genuine role of the etymon morpheme during processing of MSA while circumventing possible episodic and strategic confounds on the one hand, and maintaining comparability with previous research in the field on the other.

\section{Experiment 1: cross-modal priming of etymon morphemes}

On an etymon hypothesis, the basic unit of morphological organization is biliteral, consisting of two consonants. On the classical root hypothesis it is tri-literal. The two accounts are asymmetrical in the following manner: two words can be morphologically related in terms of a shared etymon even though they do not share the same root. Thus, a pair of words like [fas'ala/fas ama] "separate/split" 
share only a semantic relationship according to the classical root approach because they are formed from two distinct roots $\left\{\mathrm{fs}^{\mathrm{f}} 1\right\}$ and $\left\{\mathrm{fs}^{\mathrm{f}} \mathrm{m}\right\}$. The etymon account considers them to be morphologically related since they share the etymon $\left\{f, s^{\mathrm{f}}\right\}$. Do such pairs of words show morphologically-based priming effects?

Generally, morphologically related words are also related along semantic as well as formal (i.e. phonological and orthographic) lines. The close correlation of morphology with semantic and formal factors, especially in languages like English, Dutch and French, gives some plausibility to arguments that morphological priming effects can be explained on a phonological-semantic account (Rueckl, Mikolinski, Raveh, Miner, \& Mars, 1997). To support a strictly morphologically-based account, one needs to factorially vary the relation between prime and target along semantic and formal dimensions. In this experiment we attempt to meet these requirements, as illustrated in Table 1, by using pairs of prime targets that are (1a) morphologically and semantically related, (1b) morphologically related but semantically unrelated, $(2 a, b)$ morphologically unrelated but phonologically related and $(3 a, b)$ unrelated control words.

In condition 1a, with pairs like [mubtallun]/[waabilun] "wet"/“downpour" and [dayfun]/[fadiilatun] "guest"/"virtue", the auditory prime is morphologically related to the visual target in the sense of sharing an etymon but not a root, and the relationship between the two is synchronically semantically transparent as determined in a pre-test. We refer to this type of prime target relation as [+Etymon + Sem]. This condition will allow us to determine if pairs of words sharing an etymon prime one another, even when they do not share a tri-literal root. In condition $1 \mathrm{~b}$, labelled [+Etym -Sem], we go a step further and use prime-target pairs

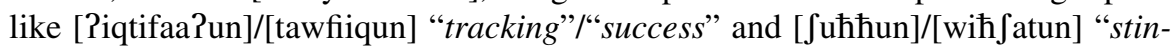
giness"/“loneliness", which are morphologically related, but semantically unrelated. If the use of the etymon as a structural unit is not contingent on the existence of a synchronically transparent semantic relationship between the prime and target, then we should observe comparable priming effects in the $[+$ Etym + Sem $]$ and the [+Etym -Sem] conditions.

Conditions $2 \mathrm{a}$ and $2 \mathrm{~b}$, labelled [-Etym + Phon], are the respective phonological controls for conditions $1 \mathrm{a}$ and $1 \mathrm{~b}$, and consist of prime and target pairs like [baliidun]/[waabilun] "stupid"/"downpour", [faatuuratun]/[tawfiiqun] "bill"/“success". These pairs show the same amount of segmental overlap as those in conditions 1a and $1 \mathrm{~b}$, but are neither morphologically nor semantically related.

Note that this phonological control condition is different from that defined for English (Feldman \& Soltano, 1999; Marslen-Wilson et al., 1994) or other nonconcatenative morphologies (Frost et al., 1997, in press) in that the form overlap is not linear as in [kataba]/[katama] "write"/"conceal" but non-linear as in [baliidun]/[waabilun]. This is a more appropriate phonological control condition in MSA for at least two reasons. First, the form overlap between prime and target in the $[+$ Etym + Sem $]$ is also non-linear in that the two etymon consonants $/ b, 1 /$ shared by the pair [mubtallun]/[waabilun] are not in the same right-to-left position. Second, using linear form overlap would amount to providing the system with information from the vocalic and consonantal morphemes at the same time. In the [kataba]/ 
Table 1

Example prime target pairs for each condition with Arabic script, phonetic transcription and English gloss ${ }^{\mathrm{a}}$

\begin{tabular}{|c|c|c|}
\hline & Prime & Target \\
\hline 1a: [+Etym, +Sem] & $\begin{array}{c}\text { مبثل } \\
\text { [mubtallun] } \\
\text { "wet" }\end{array}$ & $\begin{array}{c}\text { وابل } \\
\text { [waabilun] } \\
\text { “downpour” }\end{array}$ \\
\hline 2a: [-Etym +Phon] & $\begin{array}{c}\text { بليد } \\
\text { [baliidun] } \\
\text { "stupid" }\end{array}$ & $\begin{array}{c}\text { وابل } \\
\text { [waabilun] } \\
\text { “downpour” }\end{array}$ \\
\hline 3a: [Unrelated] & $\begin{array}{c}\text { شهادة } \\
\text { [ } \text { [ ahaadatun] } \\
\text { "testimony" }\end{array}$ & $\begin{array}{c}\text { وابل } \\
\text { [waabilun] } \\
\text { "downpour" }\end{array}$ \\
\hline 1b: [+Etym -Sem] & $\begin{array}{c}\text { اقتفاء } \\
\text { [PiqtifaaPun] } \\
\text { "tracking" }\end{array}$ & $\begin{array}{c}\text { توفيق } \\
\text { [tawfiiqun] } \\
\text { "success" }\end{array}$ \\
\hline 2b: [-Etym +Phon]: & $\begin{array}{c}\text { فاتورة } \\
\text { [faatuuratun] } \\
\text { "billl" }\end{array}$ & $\begin{array}{c}\text { توفيق } \\
\text { [tawfiiqun] } \\
\text { "success" }\end{array}$ \\
\hline 3b: [Unrelated] & $\begin{array}{c}\text { غزارة } \\
\text { [yazaaratun] } \\
\text { "abundance" }\end{array}$ & $\begin{array}{c}\text { توفيق } \\
\text { [tawfiiqun] } \\
\text { "success" }\end{array}$ \\
\hline
\end{tabular}

\footnotetext{
${ }^{\text {a }}[+$ Etym + Sem $]$ is the morphologically and semantically related condition, $[+$ Etym - Sem $]$ is the morphologically but semantically unrelated condition, [-Etym + Phon] stands for the phonological overlap condition, and [Unrelated] refers to the baseline condition.
}

[katama] example the overlapping consonants in bold belong to the consonantal morpheme while the overlapping bold vowels make up the vocalic morpheme.

Finally, conditions 3a and 3b, labelled [Unrelated], with pairs like [Jahaadatun]/ [waabilun] "testimony"/“downpour", [razaaratun]/[tawfiiqun] "abundance"/ "success", which are morphologically, semantically and phonologically unrelated, provide the baseline against which priming will be assessed.

If the etymon functions as a specifically morphological cognitive organizing unit, then we ought to observe priming effects not only when prime and target share morphology and semantics but more importantly when they share morphology with- 
out semantics. Equally, etymon-based morphological facilitation should prove to be different from form priming.

\subsection{Method}

\subsubsection{Participants}

A group of 30 volunteers took part in the experiment. They were aged 16-20 years old and were pupils at the High School of Tataouine in the Southern part of Tunisia. They were native Arabic speakers and used MSA on a regular basis at school. None of them had any known history of hearing loss or speech disorder.

\subsubsection{Materials and design}

Three independent variables, morphology, semantics and phonology, were manipulated such that prime and target pairs were either morphologically and semantically related, or morphologically related but semantically unrelated, or morphologically unrelated but phonologically related. The targets were 48 MSA words of a mean letter length of 4.29 and a mean syllable length of 3.16. Half of these words were paired with three sets of primes: (a) 24 primes with which they shared an etymon and a transparent semantic relationship like [mubtallun]/[waabilun] "wet"/"downpour"; this corresponds to the [+Etym +Sem] condition; (b) 24 primes with which they were phonologically related like [baliidun]/[waabilun] "stupid"/"downpour" representing the [-Etym + Phon] condition, and based on a non-linear definition of overlap, as discussed above; (c) the last 24 primes were neutral words used to establish a priming baseline and shared no relationship, as in the example [Jahaadatun]/[waabilun] "testimony"/“downpour" (see Appendix A for the list of experimental material used).

The second half of the targets was also paired with three sets of primes: (d) 24 prime words with which they shared an etymon but an opaque semantic relationship as in [?iqtifaa?un]/[tawfiiqun] "tracking"/"success". This is the [+Etym -Sem] condition; (e) 24 primes that were related to them along the phonological lines mentioned above as in [faaturatun]/[tawfiiqun] "bill"/"success"; and (f) another 24 unrelated words as in [razaaratun]/[tawfiiqun] "abundance"/"success". The mean letter and syllable length of the primes sharing an etymon and a transparent semantics with the targets were 4 and 3.21 , respectively. In the condition where primes and targets shared an etymon but no semantics, the mean length was 4.25 letters and 3.21 syllables. The overall letter and syllable lengths in the phonological conditions were 4.16 and 3.17 , respectively. In the unrelated conditions, the mean letter and syllable lengths were 4.04 and 3.16, respectively.

In the $[+$ Etym + Sem] condition, that is condition 1a, the prime words shared 2.13 letters and 2.13 phonemes with the targets on average. Analogously, the prime words in condition $2 \mathrm{a}$, the [-Etym + Phon] condition, shared an average of 2.25 letters and 2.04 phonemes with the targets. As regards the [+Etym - Sem] condition, prime and target pairs overlapped by 2.29 letters and 2.29 phonemes on average, while the average amount of shared letters and phonemes between primes and targets in condition $3 \mathrm{~b}$, that is the [-Etym + Phon] condition, was 2.25 and 1.96 , 
respectively. None of the experimental word pairs shared a skeletal or a vocalic morpheme (McCarthy, 1979, 1981).

Semantic relatedness was assessed in a pre-test in which 15 native Arabic judges took part. Primes and targets are considered as sharing a transparent semantic relationship only if at least $80 \%$ of the judges rated them 7 or more on a 1-to-9point scale with 1 being "unrelated" and 9 being "highly related". The pairs considered as semantically opaque were rated 3 or less by at least $80 \%$ of the participants. A morphological relationship between primes and targets was determined on linguistic distributional grounds (Bohas, 1997). A lack of reliable word frequency counts led us to administer a familiarity judgement pre-test. Fifteen other native Arabic judges were asked to rate each of the potentially experimental words on a scale of 1 (very rare) to 5 (very familiar). Only those words that were rated 3 or more by at least $80 \%$ of the judges were selected for the experiment. Given the nonexistence of any neighbourhood frequency counts, we opted for a within-word design to avoid any artefacts due to this factor.

Forty-eight unrelated prime-target filler pairs matched with each of the experimental pairs on familiarity and form class were selected. A further 96 words were selected and paired with non-words. Half of these word-non-word pairs shared form overlap and half did not and served to match the filler word-word pairs. Twenty-two catch trials were also constructed consisting of 11 word-word pairs and word-nonword pairs. Practice trials comprised 36 prime-target pairs with 18 word responses and 18 non-word responses. The pseudowords were constructed by combining a non-existing consonantal morpheme with an existing vocalic morpheme and an existing skeletal morpheme. Thus, three experimental lists were constructed each containing 250 pairs of which 125 were word-word pairs and 125 were wordpseudoword pairs. The proportion of related items in each list, including morphologically related and phonologically related items, did not exceed 30\%. Subjects were assigned randomly to one of the lists and were not presented with the same prime or target more than once. The stimuli were rotated within conditions in each list in a Latin-square design. Because MSA words are phonologically ambiguous and can be read in more than one way unless they contain vowel diacritics or long vowels, we used target probes that contain a long vowel and are unequivocally legible in only one way. We avoided using words that can be disambiguated only with vowel diacritics because the latter are almost never used in adult reading material.

\subsubsection{Procedure}

All the prime words were recorded by a native speaker of Arabic and digitized with a sampling rate of $44 \mathrm{kHz}$. They were then downsampled to $22 \mathrm{kHz}$ using the CoolEdit program and stored on a portable PC. Two portable PC monitors were used to test subjects in twos in a quiet room. They heard the stimuli at a comfortable level through HD 250 Sennheiser headphones. The sequence of stimulus events within each trial was as follows: a $1000 \mathrm{~ms}$ silence was followed by an auditory prime; immediately at its offset a target was displayed on the screen for $2000 \mathrm{~ms}$. A new trial would start at the end of this period unless the subject responded within the 
time-out. Timing and response collection were controlled by a laptop PC running the DMDX package. ${ }^{2}$ Participants were instructed to make a lexical decision as quickly and as accurately as possible by pressing a "YES" or "NO" key. The "YES" response was always made by the dominant hand. To make sure that participants attended to the auditory prime they were asked at intervals to write down the prime word of the catch trials. The experiment, which lasted about $20 \mathrm{~min}$, started with the 36 practice trials followed by the rest of the stimuli.

\subsection{Results}

Mean response times (RTs) and mean error frequencies in each condition were calculated for each participant and each item, and were subjected to separate analyses of variance (ANOVAs) with participants $(F 1)$ and items $(F 2)$ as random factors. Cut-offs were established at two standard deviations below or above the mean response of each subject. This procedure eliminated a small percentage of the data $(0.08 \%)$, which was not replaced. The overall error rate was $5 \%$. Table 2 shows the mean RT, the standard deviation and the error rate for the experimental conditions used. Fig. 2 shows the main priming effects.

Error analysis did not yield any statistically significant differences between the different conditions. Turning to the RT analyses, we conducted two separate sets of two-way ANOVAs with two three-level factors Priming Condition and Version. ${ }^{3}$ The first ANOVA concerned the first three conditions (+Etym +Sem, +Phon, Unrelated) and yielded a significant priming effect $(F 1(1,29)=14.08$, $P<0.001 ; F 2(1,23)=10.29, P<0.003)$. Planned comparisons, using the Bonferroni test throughout, demonstrated a significant difference between the morphological condition [+Etym + Sem] and the phonological condition [-Etym +Phon] and between the $[+$ Etym + Sem $]$ and the unrelated conditions. There was no difference between the $[-$ Etym + Phon] and the unrelated conditions. A similar analysis was conducted on the second three conditions (+Etym - Sem, -Etym +Phon, Unrelated) and again there was a significant main effect of priming $(F 1(1,29)=24, P<0.001 ; F 2(1,23)=8.39, P<0.01)$. Planned comparisons showed significant differences between the $[+$ Etym - Sem] condition and both the $[-$ Etym + Phon $]$ and the unrelated conditions. The $[-$ Etym + Phon $]$ condition and the unrelated condition did not differ.

We further ran an overall three-way ANOVA on items and participants. The first and second factors were, as before, Priming Condition with three levels (" + Etymon", " + Phonology" and "Unrelated") and Version. The additional factor was Opacity, with the two levels "transparent" (those items belonging to the set

\footnotetext{
${ }^{2}$ The DMDX experimental software is programmed by Jonathan Forster at the University of Arizona. DMDX is a member of the DMASTR family of experimental software developed at Monash University and the University of Arizona by K.I. Forster and J.C. Forster. For further information see: http:// www.u.arizona.edu/ kfortser/dmdx/dmdxhp.htm

${ }^{3}$ The factor version picks up the variance due to the assignment of items and participants to experimental versions. The results of this aspect of the analysis are not reported in detail here. There were no significant main effects or interactions with this factor.
} 
Table 2

Cross-modal mean lexical decision times (RT), standard deviations (SD) and percentage error rates (\%Error)

\begin{tabular}{|c|c|c|c|c|c|}
\hline & Prime & Target & RT (ms) & SD & \%Error \\
\hline 1a: $[+$ Etym, + Sem $]$ & $\begin{array}{c}\text { مبتل } \\
\text { [mubtallun] } \\
\text { "wet" }\end{array}$ & $\begin{array}{c}\text { وابل } \\
\text { [waabilun] } \\
\text { "downpour" }\end{array}$ & 605 & 60 & 5 \\
\hline 2a: [-Etym +Phon] & $\begin{array}{c}\text { بليد } \\
\text { [baliidun] } \\
\text { "stupid" }\end{array}$ & $\begin{array}{c}\text { وابل } \\
\text { [waabilun] } \\
\text { “downpour" }\end{array}$ & 678 & 81 & 3 \\
\hline 3a: [Unrelated] & $\begin{array}{c}\text { شهاد } \\
\text { [ } \text { [ ahaadatun] } \\
\text { "testimony" }\end{array}$ & $\begin{array}{c}\text { وابل } \\
\text { [waabilun] } \\
\text { "downpour" }\end{array}$ & 666 & 90 & 4 \\
\hline 1b: [+Etym -Sem] & $\begin{array}{c}\text { اقتفاء } \\
\text { [?iqtifaa Pun] } \\
\text { "tracking" }\end{array}$ & $\begin{array}{c}\text { توفيق } \\
\text { [tawfiiqun] } \\
\text { "success" }\end{array}$ & 601 & 57 & 6 \\
\hline 2b: [-Etym +Phon]: & $\begin{array}{c}\text { فاتورة } \\
\text { [faatuuratun] } \\
\text { "bill" }\end{array}$ & $\begin{array}{c}\text { توفيق } \\
\text { [tawfiiqun] } \\
\text { "success" }\end{array}$ & 676 & 87 & 5 \\
\hline 3b: [Unrelated] & $\begin{array}{c}\text { غرارة } \\
\text { [Yazaaratun] } \\
\text { "abundance" }\end{array}$ & $\begin{array}{c}\text { توفيق } \\
\text { [tawfiiqun] } \\
\text { "success" }\end{array}$ & 665 & 73 & 7 \\
\hline
\end{tabular}

of the [+Etym + Sem] condition) and "opaque" (those items belonging to the [+Etym - Sem] set). The results show a strong main effect of priming condition $(F 1(1,29)=19.93, P<0.001 ; F 2(1,23)=14.61, P<0.001)$. The main effect of Opacity was not significant $(F<1)$ and there was no interaction with Priming Condition. Furthermore, the effects of Version failed to reach significance $(F 1<1, F 2<1)$. None of the possible interactions between these factors were significant $(F 1<1, F 2<1)$. Planned comparisons between conditions using the Bonferroni test showed the [+Etym] condition to be significantly different both from the phonological condition (Bonferroni, $P<0.05$ ) and the unrelated condition (Bonferroni, $P<0.05$ ). Finally, the difference between the phonological condition and the unrelated condition was not significant (Bonferroni, $P>0.05$ ).

\subsection{Discussion}

The above results offer a clear answer to the question of whether a morphological 


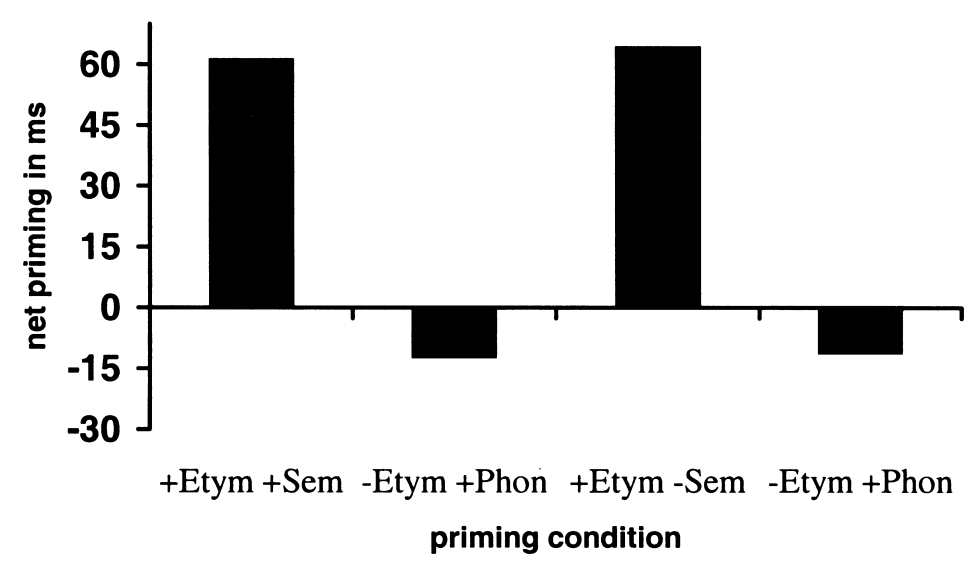

Fig. 2. Priming effects for Experiment 1, showing the test-baseline difference for the two sets of experimental conditions $[+$ Etym + Sem $]$, $[-$ Etym + Phon $]$ and $[+$ Etym - Sem $],[-$ Etym + Phon $]$.

priming effect can be obtained even if the relationship between prime and target is based on the bi-literal etymon rather than the tri-literal root. Two word forms sharing an etymon morpheme but not a root do indeed prime each other in the cross-modal priming task. This etymon-based priming does not seem to be contingent on the prime and target sharing a semantically transparent relationship. The amount of facilitation in the semantically transparent [+Etym + Sem] condition and the semantically opaque [+Etym $-\mathrm{Sem}$ ] condition is 61 and $64 \mathrm{~ms}$, respectively. The presence of a strong morphological priming effect for semantically unrelated pairs, and the absence of an additional priming advantage for semantically related pairs, is quite different from what we and others have previously observed for English (e.g. Marslen-Wilson et al., 1994), but consistent with existing research into Semitic morphology using priming techniques. Working in Hebrew, Frost et al. (1997) also observed no difference between Hebrew primes and targets sharing a morphological unit and a transparent semantic relationship and those sharing a morphological unit but an opaque semantic relationship. We have found similar effects in root priming experiments in Arabic (Boudelaa \& Marslen-Wilson, 2000). What seems to be crucial for the emergence of morphological priming in Semitic languages is not that the prime and target share a transparent semantic relationship but that they share a structurally defined morphological unit.

The results further show that phonologically related but morphologically unrelated primes and targets give rise to an average $11.5 \mathrm{~ms}$ non-significant inhibition which is in keeping with results from other research using cross-modal priming (e.g. Marslen-Wilson et al., 1994). As stated earlier on, our phonological condition is different from the sort of phonological conditions currently used in similar studies of Hebrew morphology (Frost et al., 1997) or English (Marslen-Wilson et al., 1994) in that it is built on the basis of a non-linear definition of form overlap. 


\section{Experiment 2: masked priming of etymon morphemes}

In this experiment we seek to gather further evidence for the use of the etymon morpheme as a processing unit in MSA, drawing on masked priming. As noted earlier, the masked priming task offers a useful complement to the cross-modal task, being less open to possible strategic influences, and rendering possible semantic confounds highly unlikely. Should we obtain converging evidence, the argument for a morphological unit that is more fine-grained than the classical three-consonantal root will be set on firmer grounds. Being highly sensitive to form overlap, masked priming will allow us to evaluate more directly the respective use of morphological and formal factors (Forster \& Veres, 1998). It will also allow us to evaluate more directly the claim that non-linear form overlap in non-concatenative morphologies is the appropriate control for prime-target pairs with non-linear form overlap.

We make the same contrasts as in Experiment 1 (see Table 1). Because masked priming is sensitive to form overlap, the crucial difference with Experiment 1 is the emphasis on the contrast between morphological priming and form priming. This will be addressed by comparing the morphologically related conditions [+Etym + Sem] and [+Etym -Sem] with the phonological condition [-Etym +Form]. The finding earlier of cross-modal priming both for semantically transparent and semantically opaque pairs is evidence that morphological effects in Arabic cannot be reduced to semantic factors. If we find that the two morphological conditions $[+$ Etym + Sem $]$ and $[+$ Etym - Sem $]$ pattern together and differ from the [-Etym +Form] condition, this will be an argument against a "form plus meaning" interpretation of the data.

\subsection{Method}

\subsubsection{Participants}

Another 30 volunteers from the same age range as before took part in the experiment. They were native Arabic speakers and used MSA on a regular basis for their high school studies.

\subsubsection{Materials and design}

The same design and experimental material were used as in Experiment 1. The only change was a reduction in the number of unrelated fillers, giving an overall $50 \%$ of unrelated pairs. There is less need to dilute the proportion of related items than in cross-modal priming because participants are not aware that there is a prime at all, related or not.

The reason for using otherwise identical material in cross-modal and masked priming is twofold. First, this allows a highly controlled comparison of the relative contributions of semantic and formal factors to morphological effects (cf. Frost et al., in press). Second, the whole material set we used consisted of primes and targets that were orthographically unambiguous. 
Boudelaa and Marslen-Wilson

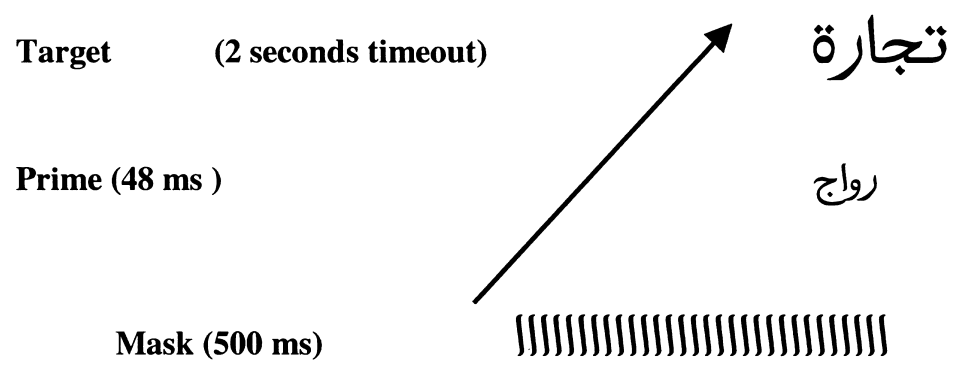

Fig. 3. Sequence of events in the masked priming experiment. The font size was 36-, 20-, and 30-point for the target, the prime and the mask, respectively.

\subsubsection{Procedure}

The same hardware and software were used as in the previous experiment. Each trial consisted of three visual events. The first was a forward pattern mask, in the form of a sequence of 28 vertical lines in a 30-point traditional Arabic font size. We chose this mask on the basis of few pre-testing sessions in which we compared it to the standardly used hash marks. The second event was a prime word written without diacritics in 24-point using the same font. The prime display duration was $48 \mathrm{~ms}$. The third event was a target word or non-word written without diacritics in a 34point font size. It was displayed for $2000 \mathrm{~ms}$. Since there is no upper case/lower case letter opposition in MSA, the targets had a larger font size than the primes to make sure the latter were appropriately masked. Fig. 3 illustrates the event sequence used in the experiment.

All stimuli were presented in white on a light blue background. Subjects were asked to make a quick and accurate lexical decision about the target by pressing a "YES" or "NO" key. The experiment lasted about $15 \mathrm{~min}$ and started with 36 practice trials followed by the experimental trials.

\subsection{Results}

RT and error data were collected and cleaned as before. Only $0.06 \%$ of the data were outside a range of 2 standard deviation from the respective subject's mean and were removed without being replaced. The effects of the related conditions (i.e. + Etym + Sem, +Etym - Sem, - Etym + Phon) were assessed relative to the unrelated baseline. The condition means are presented in Table 3, and the priming effects are summarized in Fig. 4.

Error analyses did not yield any significant effects either by subjects or items. For the RT data, separate two-way ANOVAs were conducted on participants and items, with the factors of Prime Condition and Version. For the $[+$ Etym + Sem] set there was a strong effect of Prime Condition $(F 1(1,29)=19.30, \quad P<0.001$; $F 2(1,23)=16.95, P<0.001)$. Planned comparisons using a Bonferroni test showed that the semantically transparent morphological condition [+Etym 
Table 3

Masked mean lexical decision times (RT), standard deviations (SD) and percentage error rates (\%Error) and the amount of priming in the different experimental conditions

\begin{tabular}{|c|c|c|c|c|c|}
\hline & Prime & Target & RT (ms) & SD & \%Error \\
\hline 1a: $[+$ Etym, + Sem $]$ & $\begin{array}{c}\text { مبتل } \\
\text { [mubtallun] } \\
\text { "wet" }\end{array}$ & $\begin{array}{c}\text { وابل } \\
\text { [waabilun] } \\
\text { “downpour" }\end{array}$ & 627 & 45 & 7 \\
\hline 2a: [-Etym +Phon] & $\begin{array}{c}\text { بل } \\
\text { [baliidun] } \\
\text { "stupid" }\end{array}$ & $\begin{array}{c}\text { وابل } \\
\text { [waabilun] } \\
\text { “downpour” }\end{array}$ & 658 & 56 & 7 \\
\hline 3a: [Unrelated] & $\begin{array}{c}\text { شهاد } \\
\text { [ } \text { ahaadatun]. } \\
\text { "testimony" }\end{array}$ & $\begin{array}{c}\text { وابل } \\
\text { [waabilun] } \\
\text { “downpour” }\end{array}$ & 679 & 66 & 6 \\
\hline lb: [+Etym -Sem] & $\begin{array}{c}\text { اقتفاء } \\
\text { [?iqtifaaPun] } \\
\text { "tracking" }\end{array}$ & $\begin{array}{c}\text { توفيق } \\
\text { [tawfiiqun] } \\
\text { "success" }\end{array}$ & 613 & 39 & 8 \\
\hline 2b: [-Etym +Phon]: & 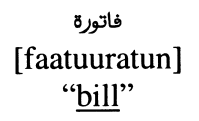 & $\begin{array}{c}\text { توفيق } \\
\text { [tawfiiqun] } \\
\text { "success" }\end{array}$ & 634 & 49 & 5 \\
\hline 3b: [Unrelated] & $\begin{array}{c}\text { غرارة } \\
\text { [yazaaratun] } \\
\text { "abundance" }\end{array}$ & $\begin{array}{c}\text { توفيق } \\
\text { [tawfiiqun] } \\
\text { "success" }\end{array}$ & 657 & 55 & 6 \\
\hline
\end{tabular}

+ Sem] was significantly different from its phonological control $(P<0.05)$ and from the unrelated control $(P<0.05)$. The difference between the $[-$ Etym + Phon] condition and the unrelated condition was not significant by items or participants $(P>0.05)$ despite a clear numerical tendency towards facilitation $(21 \mathrm{~ms})$. Turning to the $[+$ Etym - Sem] set, we again see a significant effect of Prime Condition $(F 1(1,29)=11.47, P<0.01 ; F 2(1,23)=9.59, P<0.01)$. Planned comparisons showed that the semantically opaque morphologically related condition (i.e. +Etym -Sem) was significantly different from its unrelated control $(P<0.05)$ and from its phonological control $(P<0.05)$. The difference between the phonological condition and the unrelated condition was not significant (Bonferroni, $P>0.05)$. We also compared the amount of priming obtained in the [+Etym + Sem $]$ condition with that obtained in the [+Etym - Sem] condition using an independent sample two-tail $t$-test, which yielded no significant difference.

We further conducted an overall three-way ANOVA, with the three-level factors Prime Condition and Version, and the additional factor Opacity comprising the two 


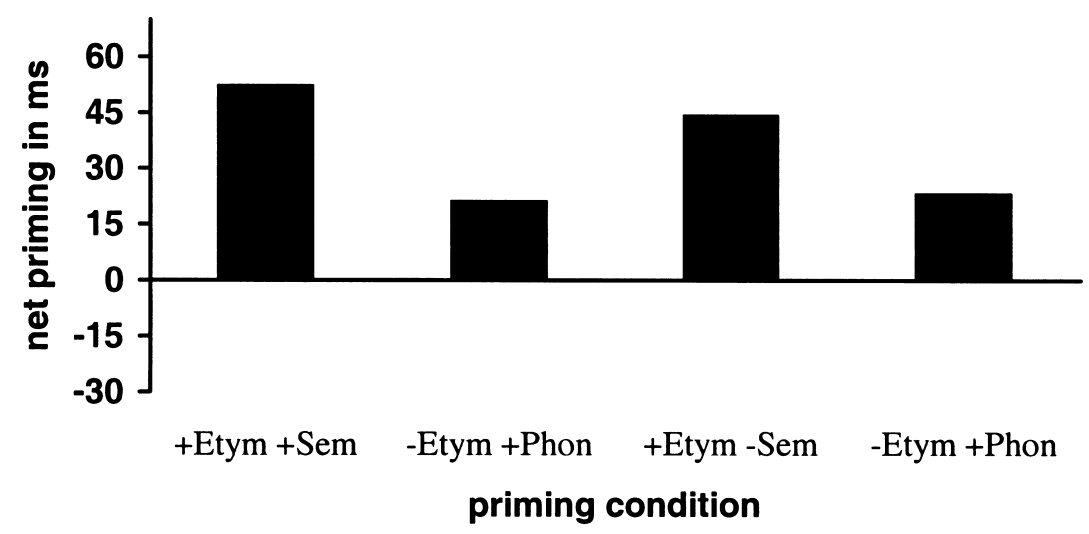

Fig. 4. Priming effects for Experiment 2, showing the test-baseline difference for the two sets of experimental conditions $[+$ Etym + Sem $]$, $[-$ Etym + Phon $]$ and $[+$ Etym - Sem $],[-$ Etym + Phon $]$.

levels transparent $[+\mathrm{Sem}]$, and opaque $[-\mathrm{Sem}]$. There was a strong main effect of Prime Condition $(F 1(1,29)=13.49, P<0.001 ; F 2(1,23)=14.49, P<0.001)$. The effects of Opacity and Version were not significant nor were the effects of any double or treble interaction between these factors $(F 1<1, F 2<1)$. In planned comparisons between conditions, there were significant differences between the [+Etym] condition and the phonological condition (Bonferroni, $P<0.05$ ) on the one hand, and between the $[+$ Etym] condition and the unrelated condition on the other (Bonferroni, $P<0.05$ ). The difference between the phonological condition and the unrelated condition was not significant (Bonferroni, $P>0.05$ ).

\subsection{Discussion}

The results obtained with masked priming are similar to those found using a crossmodal priming paradigm. They suggest that etymon priming appears not only when the prime and target are morphologically and semantically related but also when they share a solely morphological relationship with no semantic correlate. However, the two paradigms offer different though predictable results with respect to formbased priming. While form overlap is if anything inhibitory in cross-modal priming, it tends to be facilitatory in the masked paradigm. This indicates that non-linear form overlap as in [faatuuratun]/[tawfiiqun] "bill"/"success", where the overlapping segments are in bold, is a viable alternative to a purely linear form overlap (e.g. bulletin/bullet) in the context of a non-concatenative morphology language. Independent support for this claim is provided by other studies showing that the consonantal material in MSA corresponds to a structurally independent morphemic unit whose component consonants are not pre-anchored. In other words, the segments of the consonantal morpheme are not assigned a pre-specified position in the overall structure of the surface form (Berg \& Abd-El-Jawad, 1996; Prunet et al., in press). For example, the radical letter /b/ of the morpheme $\{$ btr $\}$ can surface as an onset of the first syllable in [batar] "cut down", as an onset of the second syllable in [?inbatar] 
"get cut down" or as a coda of the first syllable of the form [mabtuur] "severed". This is not the case in a concatenative morphology language like English where a more stable phonological specification of lexical forms is available at least for monomorphemic words. The segmental make-up of English forms is much less prone to change position as a result of derivational and inflectional processes.

Overall, the masked priming results are consistent with those obtained in Experiment 1 and point clearly to the fact that a morphological unit that is more fine-grained than the classical three-consonantal morpheme can serve as an organizing unit in MSA.

\section{General discussion}

At least three linguistic models contend to formally describe and account for Semitic morphology. These are the classical root and pattern approach, the multilinear autosegmental approach, and the etymon approach. Although they overlap in several respects, their working assumptions are distinct enough to raise different questions with respect to mental processing and representations. Previous psychological research into morphological processing and representation in Semitic languages has been exclusively undertaken within the framework of the root and pattern model (Barakai, 1980; Berg \& Abd-El-Jawad, 1996; Deutsch et al., 1998; Feldman et al., 1995; Frost \& Deutsch, 1998; Frost et al., 1997; Mimouni et al., 1995; Prunet et al., 1998 , in press). In contrast, the present study set out to assess the use of the etymon morpheme during word processing in MSA, departing from this tradition. Our argument is straightforward: if the classically cited sets like [kataba] "write", [kaataba] "correspond", [kutiba] "be written", [kutubun] "books", [maktuubun] "written", etc., which share three consonants $\{k t b\}$, are morphologically related and yield typical morphological priming effects, then sets like [batta] "cut down", [batara] "cut off", [?inbatara] "be separated", [bataka] "separate", [batala] "cut down", [balata] "sever", which share two consonants $\{b t\}$, are morphologically related and should consequently yield comparable priming effects. Furthermore, since morphological priming seems not to be dependent on a transparent semantic relationship in Semitic languages (Frost et al., 1997), we reasoned that etymon priming may be obtained even when prime and target pairs are semantically opaque. The results of the cross-modal priming experiment show that there is a strong etymon priming effect irrespective of semantic transparency. The masked priming paradigm also yields strong etymon priming effects providing converging evidence for the role of the etymon morpheme during MSA processing. The independence of etymon priming effects from form overlap is demonstrated by the complete absence of phonological priming in Experiment 1 and the significant difference between morphologically and orthographically related pairs in the Experiment 2.

\subsection{Etymons and roots as lexical units}

Evidence in favour of the etymon as a processing and a representational unit calls into question the status of the three-consonantal root as a morphologically relevant 
unit in MSA. This does not mean, however, that the language processor would not pick up on the strong regularities offered by the three-consonantal root. Since every root morpheme comprises theoretically an etymon plus a third consonant, the effects of the root in language processing follow automatically from an etymon standpoint. Indeed we have ourselves found strong morphological effects between primes and targets sharing a three-consonantal root morpheme regardless of whether or not the morphological relation is accompanied by semantic transparency (Boudelaa \& Marslen-Wilson, 2000). Our point is that, at least for a subset of MSA vocabulary, tri-consonantal root effects (Boudelaa \& Marslen-Wilson, 2000; Mimouni et al., 1995; Prunet et al., 1998) do reflect an etymon effect because the core meaning of words in MSA is conveyed by the etymon not the root (Bohas, 1997; Hurwitz, 1966).

The existence of three-consonantal roots in large numbers is not a remarkable fact about MSA or any other Semitic language (Ratcliffe, 1998). What is important about Semitic languages, however, is that the three-consonantal structure is imposed by the skeletal morpheme. This is so because non-derived forms may have a great variety of phonological shapes but surface word forms do conform to a canonical skeletal shape. This means that the derivation of surface word forms in MSA is a goal-oriented process, which performs whatever operation is necessary to meet the requirement of the skeleton. The opposing would be that the preponderance of threeconsonantal roots accounts for the skeleton containing three-consonantal slots. That this is not the case can be demonstrated by considering the pluralization of two and five consonantal primitive nouns like [?abun] "father" and [safarzalun] "quince". The plural template consistently contains three consonants and more rarely four, and consequently an epenthetic consonant is added to the bi-consonantal stem [?abun] to obtain the plural form [?aabaa?un], but a consonant is deleted from the five-consonantal stem [safarzalun] in order to have the plural from [safaarizun]. Consonant addition and consonant deletion are thus two phonological processes that are morphologically triggered by the skeleton requirement.

Examples of morphologically motivated phonological changes abound in verb morphology as well and illustrate the claim that it is morphology rather than any independent restriction on the size of "roots" which accounts for the seemingly triconsonantal aspect of the MSA lexicon (see Ratcliffe, 1998 for a diachronic discussion). The etymon approach offers an account of the relationship between surface forms like [batta], [batara], [balata] without recourse to any additional mechanism over and above those used by the traditional root approach. Saying that underived MSA items start off as two-consonantal etymons and are expanded into a three-consonantal form through various phonological processes (gemination, consonant epenthization, etc.) in order to be brought into conformity with the skeleton morpheme is identical to the claim that consonants are added to or deleted from pluralized primitive nouns in keeping with the requirement of the skeleton.

Interesting additional evidence to support this analysis comes from some recent work by Frost, Deutsch, and Forster $(1997,2000)$ who found that the parsing of Hebrew words into roots and word patterns collapsed when the experimental material consisted of words derived from the so-called defective roots, that is roots 
having one consonant missing in some of their surface forms. For example, the defective root $\{\mathrm{nfl}\}^{4}$ "falling" combined with the active pattern $\{$ hi- $-\mathrm{i}-\}$ surfaces as [hipil] instead of *[hinpil] as expected. By contrast, the non-defective root $\{\mathrm{spk}\}$ "being enough" yields the expected form [hispik] with its three consonants. When [hispik]-like forms are preceded by [hipil]-type forms no word pattern priming occurs. Upon adding a third consonant illegally to defective roots and using them as primes followed by existing non-defective forms (e.g. Prime *[hinpil]-Target [hispik]) the parsing of surface forms into roots and word patterns was at work again and word pattern priming was obtained. It is tempting to explain these effects in terms of the claim that one of the three consonants is present only to meet the requirement imposed by the skeletal template and is not critical for the meaning of the root morpheme. Put differently, the three-consonantal root is important not because it conveys a core semantic meaning, which is arguably conveyed by the etymon for a large subset of Semitic vocabulary, but because it provides the language processor with the canonical timing morpheme with three-consonantal slots appropriately filled.

\subsection{Non-concatenative morphological processing in a wider context}

The present results put new constraints on existing models of morphological processing and representation. For example, the dual interactive model of Frost et al. (1997) posits two levels of representations corresponding to a word level and a subword root level. The two levels are linked such that the root morpheme can be accessed at the lexical level from word forms containing that root or alternatively by directly following a process of morphologically decomposing the orthographic structure. In order to accommodate our results this model would have to either posit a second subword level of representation corresponding to the etymon or else dispense with the three-consonantal root level and maintain only the etymon as a subword unit level. The first scenario would imply that the three levels of representations are interconnected so that the language processor accesses roots and etymons at the lexical level from word forms containing them or by directly following a parsing process of the orthographic structure or phonological structure of whole word units. The second scenario would imply that the etymon level of representation is connected to word units and that etymon recognition occurs either indirectly through whole word forms or directly through the decomposition of surface forms into etymons and word patterns.

A second possible account could be suggested along the lines of a model which clearly spells out the difference between claims about access representations and those about lexical entries (Marslen-Wilson et al., 1994). Access representations refer to the perceptual target for lexical access, whereas lexical entries define the core representation of lexical units, which abstract away from surface forms. Given the highly abstract nature of the etymon morpheme, its priming effects

\footnotetext{
${ }^{4}$ Note that the /f/ and the /p/ are in complementary distribution in Hebrew in the sense that the /f/ surfaces only word finally whilst the /p/ surfaces word initially and medially.
} 
are best explained at the level of lexical entries. Thus, surface word forms sharing the same etymon would be linked at the level of lexical entry. Because words sharing the same root share necessarily the same etymon, they are considered to map onto the same abstract lexical entry corresponding to the appropriate etymon. Nevertheless, the Marslen-Wilson et al. (1994) model would have to be extended to allow semantically opaque but morphologically related words to be linked to the same etymon or lexical entry, in order to account for the priming effects observed in our semantically opaque pairs. Although the degree of phonological abstractness assumed by this model allows it to correctly predict a lack of allomorphic effects on the processing, it remains to be determined how it can accommodate in its localist version the fact that the same abstract etymon $\{\mathrm{f}, \mathrm{q}\}$ can surface in the order "labiodental-uvular" as in [?iqtifaa?un] "tracking" and in the order "uvular-labiodental" as in [tawfiiqun] "success" while still yielding significant priming effects.

A third possible account can be suggested in keeping with connectionist distributed models of morphology which posit that morphological priming effects emerge as a result of a synergistic interaction between form and meaning (Plaut \& Gonnerman, 2000; Rueckl et al., 1997; Rueckl \& Raveh, 1999). Two aspects of the etymon as an organizing unit seem problematic for this account. First, the form overlap between prime and target words is minimal in the sense that they share only two phonemes. Second, semantically opaque forms yield morphological priming effects that are similar to those yielded by semantically transparent pairs. These two aspects of the etymon indicate that morphological effects can appear without having to be directly backed either by strong form overlap or a transparent semantic relationship. Thus, the morphological effects obtained in our study do not comfort any of the existing connectionist accounts of morphology. First, the effects we have reported do not seem to be emerging as a result of form and meaning interaction (Seidenberg, 1987). Second, contrary to the key predictions of the Plaut and Gonnerman (2000) approach, we see no sign of graded effects, where priming increases as semantic and/ or phonological relatedness between the primes increases - there is no difference here between the semantically highly related pairs $[+$ Etym + Sem $]$ and semantically unrelated pairs [+Etym - Sem].

But these results do not categorically exclude a distributed network account. For example, the argument can be made that a network dealing with all the sound-tomeaning mappings within one system, and which is using one set of weights, is likely to extract the correlation between form and meaning as a result of having been presented with many other instances that follow a given mapping pattern. This means that the MSA items that are not clearly related in meaning and sound may still get dragged along by the rest of the system by virtue of the productivity of the morphology (Plaut \& Gonnerman, 2000; Rueckl et al., 1997). Accordingly, despite sharing an opaque semantic relationship pairs like [?iqtifaa?un]/[tawfiiqun] will still prime each other. This would be so because they are both part of a large set of morphologically related words exhibiting form and meaning overlap. As noted earlier, the meaning of "tracking" is absent from the form [tawfiiqun] "success", but it emerges in the surface forms [wifqun] and [wifaaqun] especially 
in the expression [wifqan + li] and [wifaaqan + li] meaning "in pursuance of". The forms [wifqun] and [wifaaqun] are deverbal nouns surfacing with the same epenthetic consonant /w/ as [tawfiiqun]. So although [?iqtifaa?un] and [tawfiiqun] are semantically opaque, they may be linked via such forms as [wifqun] and [wifaaqun].

Morphological relationships can thus be coded in the correlational structure of the language, and the network will pick up on them given sufficient exposure to the sound-to-meaning mappings of the language. Interestingly, the connectionist approach may accommodate the effects of the two-consonantal etymon and those of the three-consonantal root without having to choose between the two units. This is because it relies on a distributed representational scheme where each item has a unique pattern of activation across a set of units shared with other items in the language. In other words, the vectors representing two surface forms sharing a root will necessarily span many of the units used to represent two surface forms sharing an etymon. The viability of such a model will depend, however, on the extent to which one can distinguish an end-state connectionist model that exhibits morphological behaviour from an account where morphology is represented as an independent level. The differences between the two approaches can be determined by considering the way in which the system acquires morphological knowledge, and how it will restructure itself if impaired. In conclusion, the present results point to the fact that highly abstract morphological units which never surface on their own can play an important role during language processing. From the perspective of Semitic languages, the results argue for an approach to morphological structure in which the etymon is a primary organizing unit. This investigation was limited to cases where the morphological relationship consisted of sharing segmental overlap rather than mere featural overlap as in [rabata]/ [Yaffa] "tie up"/"refrain", where the common features are [+labial] and [+pharyngeal]. The latter type of prime-target pairs should produce priming effects, especially in the context of a theory of lexical access and representation where featural information is mapped directly onto a representation of lexical forms without having to be integrated into intermediate units like phonemes or syllables (Marslen-Wilson \& Warren, 1994). It remains to be seen, however, whether the hypothesized priming is as strong as the priming observed with bi-consonantal overlap.

\section{Acknowledgements}

We thank Mike Ford for his assistance in the preparation of the two experiments and Abdallah Megbli, Headmaster of the High School of Tataouine, Tunisia, for his generous help in providing testing facilities and access to participants for testing. We also thank Matt Davis, Fanny Meunier and Mike Page for helpful comments on an earlier version of this paper. 


\section{Appendix A. Test items used in Experiments 1 and 2}

For every item the Arabic script, an International Phonetic Alphabet transcription and an English gloss are given.

\begin{tabular}{|c|c|c|c|}
\hline \multicolumn{4}{|c|}{ Prime } \\
\hline +Etymon +Semantics & -Etymon +Form & Unrelated & Target \\
\hline فاصل & نادم & ساحر & متصف \\
\hline $\begin{array}{l}\text { /faas }{ }^{\text {ililun/ }} \\
\text { separator }\end{array}$ & $\begin{array}{c}\text { /naadimun/ } \\
\text { repentant }\end{array}$ & $\begin{array}{c}\text { /saahirun/ } \\
\text { magician }\end{array}$ & $\begin{array}{l}\text { /muntas }{ }^{\mathfrak{Q}} \text { afun/ } \\
\text { half }\end{array}$ \\
\hline ذليل & رمل & أداة & رذيلة \\
\hline $\begin{array}{c}\text { /ðaliilun/ } \\
\text { lowly }\end{array}$ & $\begin{array}{l}\text { /ramlun/ } \\
\text { sand }\end{array}$ & $\begin{array}{l}\text { /Padaatun/ } \\
\text { tool }\end{array}$ & $\begin{array}{l}\text { /raðiilatun/ } \\
\text { vice }\end{array}$ \\
\hline عبوس & حلم & زجاجة & حبل \\
\hline $\begin{array}{c}\text { /maћbuusun/ } \\
\text { imprisoned }\end{array}$ & $\begin{array}{l}\text { houlmun/ } \\
\text { dream }\end{array}$ & $\begin{array}{l}\text { /zuzaazatun/ } \\
\text { bottle }\end{array}$ & $\begin{array}{l}\text { /hablun/ } \\
\text { rope }\end{array}$ \\
\hline بار & بارد & تماثت & $\overrightarrow{~ ت ر ب ي ة ~}$ \\
\hline $\begin{array}{c}\text { /baarrun/ } \\
\text { brought up upright }\end{array}$ & $\begin{array}{l}\text { /baaridun/ } \\
\text { cold }\end{array}$ & $\begin{array}{l}\text { /qumaaSun/ } \\
\text { cloth }\end{array}$ & $\begin{array}{l}\text { /tarbijatun/ } \\
\text { upbringing }\end{array}$ \\
\hline مقصن & مقر & $\overline{5}$ & قصير \\
\hline $\begin{array}{l}\text { /miqas }{ }^{\mathrm{q}} \mathrm{s}^{\mathrm{q}} \mathrm{un} / \\
\text { scissors }\end{array}$ & $\begin{array}{l}\text { /maqarrun/ } \\
\text { site }\end{array}$ & $\begin{array}{c}\text { /kasalun/ } \\
\text { laziness }\end{array}$ & $\begin{array}{l}\text { /qas }{ }^{\text {iirun/ }} \\
\text { short }\end{array}$ \\
\hline وقور & قرية & مثلَث & رقيق \\
\hline $\begin{array}{l}\text { /waquurun/ } \\
\text { venerable }\end{array}$ & $\begin{array}{l}\text { /qar Jatun/ } \\
\text { village }\end{array}$ & 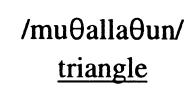 & $\begin{array}{l}\text { /raqiiqun/ } \\
\text { exquisite }\end{array}$ \\
\hline نزوة & إزاحة & سفح & زناء \\
\hline $\begin{array}{l}\text { /nazwatun/ } \\
\text { whim }\end{array}$ & $\begin{array}{l}\text { /Pizaahatun/ } \\
\text { removal }\end{array}$ & $\begin{array}{c}\begin{array}{c}\text { /safhun/ } \\
\text { mountain slope }\end{array} \\
\end{array}$ & $\begin{array}{l}\text { /zinaa?un/ } \\
\text { adultery }\end{array}$ \\
\hline كامل & جاموس & صيّاد & جملة \\
\hline $\begin{array}{l}\text { /kaamilun/ } \\
\text { whole }\end{array}$ & $\begin{array}{l}\text { /3aamuusun/ } \\
\text { buffalo }\end{array}$ & $\begin{array}{l}/ \mathrm{s}^{\mathrm{s}} \text { aj Jaadun/ } \\
\text { hunter }\end{array}$ & $\begin{array}{l}\text { /3umlatun/ } \\
\text { sum }\end{array}$ \\
\hline كمين & كلام & غول & $\bar{~}$ \\
\hline $\begin{array}{l}\text { /kamiinun/ } \\
\text { ambush }\end{array}$ & $\begin{array}{l}\text { /kalaamun/ } \\
\text { speech }\end{array}$ & $\begin{array}{l}\text { /ruulun/ } \\
\text { ogre }\end{array}$ & $\begin{array}{l}\text { /makaanun/ } \\
\text { place }\end{array}$ \\
\hline مبتز & بليد & شهيد & وابل \\
\hline $\begin{array}{l}\text { /mubtallun/ } \\
\text { wet }\end{array}$ & $\begin{array}{l}\text { /baliidun/ } \\
\text { stupid }\end{array}$ & $\begin{array}{l}\text { / Sahiidun/ } \\
\text { martyr }\end{array}$ & $\begin{array}{l}\text { /waabilun/ } \\
\text { downpour }\end{array}$ \\
\hline متوجتس & تبحسيد & متحف & جاسوس \\
\hline $\begin{array}{l}\text { /mutawa33isun/ } \\
\text { apprehensive }\end{array}$ & $\begin{array}{l}\text { /tazsiidun/ } \\
\text { embodiment }\end{array}$ & $\begin{array}{c}\text { /mathafun/ } \\
\text { museum }\end{array}$ & $\begin{array}{l}\text { /3aasuusun/ } \\
\text { spy }\end{array}$ \\
\hline
\end{tabular}


Appendix (continued)

\begin{tabular}{|c|c|c|c|}
\hline وجل & جمل & عاقر & \\
\hline $\begin{array}{c}\text { /wazalun/ } \\
\text { fear }\end{array}$ & $\begin{array}{l}\text { /3amalun/ } \\
\text { camel }\end{array}$ & $\begin{array}{c}\text { /S aaqirun/ } \\
\text { barren }\end{array}$ & $\begin{array}{c}\text { /3alaalatun/ } \\
\text { loftiness }\end{array}$ \\
\hline تواكل & متكالب & $\overline{\varepsilon l o s}$ & كلر \\
\hline $\begin{array}{l}\text { /tawaakulun/ } \\
\text { indifference }\end{array}$ & $\begin{array}{l}\text { /mutakaalibun/ } \\
\text { avid }\end{array}$ & $\begin{array}{c}\text { /dimraaun/ } \\
\text { brain }\end{array}$ & $\begin{array}{l}\text { /kalalun/ } \\
\text { weariness }\end{array}$ \\
\hline رواج & راجح & مرقف & تجارة \\
\hline $\begin{array}{l}\text { /rawaazun/ } \\
\text { marketability }\end{array}$ & $\begin{array}{l}\text { /raaziћun/ } \\
\text { preponderant }\end{array}$ & $\begin{array}{l}\text { /mawqifun/ } \\
\text { position }\end{array}$ & $\begin{array}{l}\text { /tizaaratun/ } \\
\text { trade }\end{array}$ \\
\hline سلس & مساء & ضرورة & أملس \\
\hline $\begin{array}{l}\text { /salisun/ } \\
\text { smooth }\end{array}$ & $\begin{array}{l}\text { /masaa?un/ } \\
\text { semolina }\end{array}$ & $\begin{array}{c}/ \mathrm{d}^{\text {}} \text { aruuratun/ } \\
\text { necessity }\end{array}$ & $\begin{array}{l}\text { /Pamlas/ } \\
\text { smooth }\end{array}$ \\
\hline تمام & تمثيل & عريض & موت' \\
\hline $\begin{array}{l}\text { /tamaamun/ } \\
\text { end }\end{array}$ & $\begin{array}{l}\text { /tam } \theta \text { iilun/ } \\
\text { acting }\end{array}$ & $\begin{array}{l}\text { /S } \operatorname{ariid}^{\S} \text { un/ } \\
\underline{\text { large }}\end{array}$ & $\begin{array}{l}\text { /mawtun/ } \\
\text { death }\end{array}$ \\
\hline كفاف & تفاحة & $\overline{~ ط ب ق ة ~}$ & اكتفاء \\
\hline $\begin{array}{l}\text { /kafaafun/ } \\
\text { sufficiency }\end{array}$ & $\begin{array}{l}\text { /tuffahatun// } \\
\text { apple }\end{array}$ & $\begin{array}{c}/ t^{\mathrm{S}} \text { abaqatun/ } \\
\text { layer }\end{array}$ & $\begin{array}{l}\text { /PiktifaaPun/ } \\
\text { contentment }\end{array}$ \\
\hline زهو & زهرة & جراب & اهتزاز \\
\hline $\begin{array}{c}\text { /zahwun/ } \\
\text { amusement }\end{array}$ & $\begin{array}{l}\text { /zahratun/ } \\
\text { flower }\end{array}$ & $\begin{array}{l}\text { /3iraabun/ } \\
\text { sack }\end{array}$ & $\begin{array}{c}\text { /Pihtizaazun/ } \\
\text { excitement }\end{array}$ \\
\hline لوعة & لعاب & ريف & علّة \\
\hline $\begin{array}{l}\text { /lawSatun/ } \\
\text { lovesickness }\end{array}$ & $\begin{array}{l}\text { /luSaabun/ } \\
\text { saliva }\end{array}$ & $\begin{array}{c}\text { /riifun/ } \\
\text { countryside }\end{array}$ & $\begin{array}{l}\text { /Sillaatun/ } \\
\text { sickness }\end{array}$ \\
\hline إطاحة & $\overline{b r}$ & إقالة & طريح \\
\hline $\begin{array}{l}\text { / } \text { it }^{\text {}} \text { aahatun/ } \\
\text { overthrowing }\end{array}$ & $\begin{array}{l}\text { /mumt }{ }^{\complement} \text { irun/ } \\
\text { rainy }\end{array}$ & $\begin{array}{l}\text { /Piqaalatun/ } \\
\text { resignation }\end{array}$ & $\begin{array}{l}/ \mathrm{t}^{\mathrm{a}} \text { aariihun/ } \\
\text { dumped }\end{array}$ \\
\hline دنو & دمعة & غراب & مناداة \\
\hline $\begin{array}{l}\text { /dunuwwun/ } \\
\text { approaching }\end{array}$ & $\begin{array}{l}\text { /damsatun/ } \\
\text { teardrop }\end{array}$ & $\begin{array}{l}\text { /ruraabun/ } \\
\text { crow }\end{array}$ & $\begin{array}{l}\text { /munaadaatun/ } \\
\text { calling }\end{array}$ \\
\hline تماس" & أمسية & ختان & and \\
\hline $\begin{array}{c}\text { /tamaassun/ } \\
\text { contact }\end{array}$ & $\begin{array}{l}\text { /Pumsijatun/ } \\
\text { evening }\end{array}$ & $\begin{array}{c}\text { /xitaanun/ } \\
\text { circumcision } \\
\end{array}$ & $\begin{array}{l}\text { /lamsatun/ } \\
\text { touch }\end{array}$ \\
\hline متآلف & فلاة & هار & التفاف \\
\hline $\begin{array}{c}\text { /muta?aalifun/ } \\
\text { harmonious }\end{array}$ & $\begin{array}{c}\text { /falaatun/ } \\
\text { desert }\end{array}$ & $\begin{array}{l}\text { /nahaarun/ } \\
\text { day }\end{array}$ & $\begin{array}{l}\text { /Piltifaafun/ } \\
\text { surrounding }\end{array}$ \\
\hline فضيلة & فضَة & بعال & ضيف \\
\hline $\begin{array}{c}\text { /fad } \\
\text { virtue }\end{array}$ & $\begin{array}{c}/ \text { fid }^{\complement} \mathrm{d}^{\complement} \text { atun/ } \\
\underline{\text { silver }}\end{array}$ & $\begin{array}{l}\text { /mazaalun/ } \\
\text { domain }\end{array}$ & 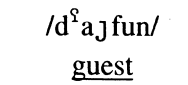 \\
\hline
\end{tabular}


Appendix (continued)

\begin{tabular}{|c|c|c|c|}
\hline & Prime & & \\
\hline +Etymon -Semantics & -Etymon +Form & Unrelated & Target \\
\hline موشم & مشاكس & غدير & شيمة \\
\hline $\begin{array}{c}\text { /muwa } \iint i m u n / \\
\text { tattoo }\end{array}$ & $\begin{array}{l}\text { /mu } \int \text { aakisun/ } \\
\text { quarrelsome }\end{array}$ & $\begin{array}{l}\text { /radiirun/ } \\
\text { pond }\end{array}$ & $\begin{array}{l}\text { /Siimatun/ } \\
\text { trait }\end{array}$ \\
\hline صفت & مرفق & ناقة & رصيف \\
\hline $\begin{array}{l}\text { /s affun/ } \\
\text { queue }\end{array}$ & $\begin{array}{l}\text { /mirfaqun/ } \\
\text { elbow }\end{array}$ & $\begin{array}{l}\text { Inaaqatun/ } \\
\text { she-camel }\end{array}$ & $\begin{array}{l}/ \text { ras }^{\S} \text { iifun/ } \\
\text { pavement }\end{array}$ \\
\hline بزئ & بمازفة & منبر & 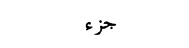 \\
\hline $\begin{array}{l}\text { /mazzuumun/ } \\
\text { clipped }\end{array}$ & $\begin{array}{l}\text { /muzaazafatun/ } \\
\text { recklessness }\end{array}$ & $\begin{array}{l}\text { /minbar/ } \\
\text { rostrum }\end{array}$ & $\begin{array}{l}\text { /3uz?un/ } \\
\text { portion }\end{array}$ \\
\hline كبّة & وكيل & رحيق & موكب \\
\hline $\begin{array}{l}\text { /kubbatun/ } \\
\text { ball of thread }\end{array}$ & $\begin{array}{l}\text { /wakiilun/ } \\
\text { representative }\end{array}$ & $\begin{array}{l}\text { /rahiiqun/ } \\
\text { nectar }\end{array}$ & $\begin{array}{l}\text { /mawkibun/ } \\
\text { procession }\end{array}$ \\
\hline تمويه & متهالك & كساد & اهتمام \\
\hline $\begin{array}{l}\text { /tamwiihun/ } \\
\text { pretending }\end{array}$ & $\begin{array}{l}\text { /mutahaalikun/ } \\
\text { exhausted }\end{array}$ & $\begin{array}{l}\text { /kasaadun/ } \\
\text { stagnation }\end{array}$ & $\begin{array}{l}\text { /Pihtimaamun/ } \\
\text { attention }\end{array}$ \\
\hline وفرة & فراشة & منكب & فرار \\
\hline $\begin{array}{l}\text { /wafratun/ } \\
\text { plenty }\end{array}$ & $\begin{array}{l}\text { /faraaatun/ } \\
\text { butterfly }\end{array}$ & $\begin{array}{l}\text { /minkabun/ } \\
\text { shoulder }\end{array}$ & $\begin{array}{l}\text { /firaarun/ } \\
\text { fleeing }\end{array}$ \\
\hline غطاء & غناء & حليب & طغيان \\
\hline $\begin{array}{l}\text { /rit aa?un/ } \\
\text { cover }\end{array}$ & $\begin{array}{l}\text { /rinaa?un/ } \\
\text { singing }\end{array}$ & $\begin{array}{l}\text { /haliibun/ } \\
\text { milk }\end{array}$ & $\begin{array}{l}\text { /t }{ }^{\mathrm{q}} \mathrm{ur} \text { Jaanun/ } \\
\text { oppression }\end{array}$ \\
\hline ساقية & واسع & حشمة & قسوة \\
\hline $\begin{array}{l}\text { /saaqijatun/ } \\
\text { barmaid }\end{array}$ & $\begin{array}{l}\text { /waasi@un/ } \\
\text { broad }\end{array}$ & $\begin{array}{l}\text { hismatun/ } \\
\text { timidity }\end{array}$ & $\begin{array}{l}\text { /qaswatun/ } \\
\text { severity }\end{array}$ \\
\hline ناسف & نفطي & شجرة & نفيس \\
\hline $\begin{array}{l}\text { /naasifun/ } \\
\text { explosive }\end{array}$ & $\begin{array}{l}/ \text { naft }^{\AA} \text { ij Jun/ } \\
\text { petrol related }\end{array}$ & $\begin{array}{c}\text { /Sazaratun/ } \\
\text { tree }\end{array}$ & $\begin{array}{l}\text { /nafiisun/ } \\
\text { precious }\end{array}$ \\
\hline رجة & مدرج & عقبة & جرار \\
\hline $\begin{array}{l}\text { /raz3atun/ } \\
\text { quake }\end{array}$ & $\begin{array}{l}\text { /madrazun/ } \\
\text { row of seats }\end{array}$ & $\begin{array}{l}\text { /Saqabatun/ } \\
\text { obstacle }\end{array}$ & $\begin{array}{l}\text { /3arrarun/ } \\
\text { tractor }\end{array}$ \\
\hline اقتطاف & قطة & وزارة & مقطوع \\
\hline $\begin{array}{l}\text { /Pqtit }{ }^{\text {aafun/ }} \\
\text { picking }\end{array}$ & $\begin{array}{l}\text { /qit }{ }^{\mathrm{q}} \mathrm{t}^{\mathrm{q}} \text { atun/ } \\
\text { she-cat }\end{array}$ & $\begin{array}{l}\text { /wizaaratun/ } \\
\text { minstry }\end{array}$ & $\begin{array}{l}/ \text { maqt }^{\S} \text { uusun/ } \\
\text { chopped off }\end{array}$ \\
\hline اختفاء & اختيار & إسطبل & خفيف \\
\hline $\begin{array}{l}\text { /PixtifaaPun/ } \\
\text { disappearance }\end{array}$ & $\begin{array}{l}\text { /Pixtijaarun/ } \\
\text { choice }\end{array}$ & $\begin{array}{c}\text { /Pis }{ }^{q} \mathrm{t}^{\mathrm{Q}} \text { ablun/ } \\
\text { stable }\end{array}$ & $\begin{array}{l}\text { /xafiifun/ } \\
\text { light }\end{array}$ \\
\hline
\end{tabular}


Appendix (continued)

\begin{tabular}{|c|c|c|c|}
\hline اقتفاء & فاتورة & 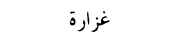 & توفيق \\
\hline $\begin{array}{l}\text { /Piqtifaa?un/ } \\
\text { tracking }\end{array}$ & $\begin{array}{c}\text { /faaturatun/ } \\
\text { bill }\end{array}$ & $\begin{array}{l}\text { /razaaratun/ } \\
\text { abundance }\end{array}$ & $\begin{array}{l}\text { /tawfiiqun/ } \\
\text { success }\end{array}$ \\
\hline وبش & بشرة ب & قوس & مشيب \\
\hline $\begin{array}{c}\text { /wabSun/ } \\
\text { trash }\end{array}$ & $\begin{array}{l}\text { /baSratun/ } \\
\text { complexion }\end{array}$ & $\begin{array}{l}\text { /qawsun/ } \\
\text { bow }\end{array}$ & $\begin{array}{l}\text { /ma Siibun/ } \\
\text { old age }\end{array}$ \\
\hline $\bar{ح}$ & بكر & صنم & حبّ \\
\hline $\begin{array}{c}\text { /mubaaћun/ } \\
\text { licit }\end{array}$ & $\begin{array}{l}\text { /bahrun/ } \\
\text { sea }\end{array}$ & $\begin{array}{c}/ \mathrm{s}^{\mathrm{S}} \text { anamun/ } \\
\underline{\text { idol }}\end{array}$ & $\begin{array}{c}\text { hubbun/ } \\
\text { love }\end{array}$ \\
\hline نقاء & نقاب & جماد & اقتناء \\
\hline /naqaa?un/ & /niqaabun/ & /3amaadun/ & /Piqtinaa?un/ \\
\hline purity & $\underline{\text { veil }}^{\prime}$ & inanimate & purchasing \\
\hline اعتكاف & فول & حظيرة & عفو \\
\hline $\begin{array}{c}\text { /PiStikaafun/ } \\
\text { devotion }\end{array}$ & $\begin{array}{l}\text { /fuulun/ } \\
\text { beans }\end{array}$ & $\begin{array}{l}\text { Ђhað }{ }^{\Upsilon} \text { iiratun/ } \\
\text { building site }\end{array}$ & $\begin{array}{l}\text { /Safwun/ } \\
\text { pardon }\end{array}$ \\
\hline تصفيق & فرو & نعجة & صفير \\
\hline $\begin{array}{l}\text { /tas }{ }^{\Upsilon} \text { afiiqun/ } \\
\text { clapping }\end{array}$ & $\begin{array}{l}\text { /farwun/ } \\
\text { fur }\end{array}$ & $\begin{array}{c}\text { /naiaztun/ } \\
\text { ewe }\end{array}$ & $\begin{array}{l}\text { /s afiirun/ } \\
\text { whistling }\end{array}$ \\
\hline جفاف & جودة & أشعَة & جوف \\
\hline $\begin{array}{l}\text { /3afaafun/ } \\
\text { dryness }\end{array}$ & $\begin{array}{l}\text { /3awdatun/ } \\
\text { excellence }\end{array}$ & $\begin{array}{l}\text { /PaSisqatun/ } \\
\text { beam }\end{array}$ & $\begin{array}{c}\text { /3awfun/ } \\
\text { cavity }\end{array}$ \\
\hline جناية & جندي & $\overline{~ ع ز ا ء ~}$ & بناة \\
\hline $\begin{array}{l}\text { /3inaajatun/ } \\
\text { felony }\end{array}$ & $\begin{array}{l}\text { /3undijJun/ } \\
\text { soldier }\end{array}$ & $\begin{array}{l}\text { /Sazaa?un/ } \\
\text { consolation }\end{array}$ & $\begin{array}{l}\text { /nazaatun/ } \\
\text { deliverance }\end{array}$ \\
\hline شَ & شحرور & هيكل & وحشة \\
\hline 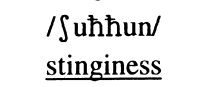 & $\begin{array}{l}\text { /Shrrurun/ } \\
\text { blackbird }\end{array}$ & $\begin{array}{l}\text { /hajkalun/ } \\
\text { skeleton }\end{array}$ & $\begin{array}{l}\text { /wih Satun/ } \\
\text { loneliness }\end{array}$ \\
\hline وارد & رمد & سبات & متردد \\
\hline $\begin{array}{l}\text { /waaridun/ } \\
\text { possible }\end{array}$ & $\begin{array}{c}\text { /ramadun/ } \\
\text { eye sourness }\end{array}$ & $\begin{array}{l}\text { /subaatun/ } \\
\text { sleep }\end{array}$ & $\begin{array}{l}\text { /mutaraddidun/ } \\
\text { hesitant }\end{array}$ \\
\hline مترقد & مقعد & سفرجل & دقَّة \\
\hline $\begin{array}{l}\text { /mutawaqqidun/ } \\
\text { burning }\end{array}$ & $\begin{array}{l}\text { /maqSadun/ } \\
\text { seat }\end{array}$ & $\begin{array}{l}\text { /safarzalun/ } \\
\text { quince }\end{array}$ & $\begin{array}{l}\text { /diqqatun/ } \\
\text { exactitude }\end{array}$ \\
\hline بغي & يابس & مخاض & اغتياب \\
\hline /barjun/ & /Jaabisun/ & $/ \operatorname{maxaad}^{\mathrm{q}} \mathrm{un} /$ & /Pi rtijaabun/ \\
\hline injustice & dried out & labor & $\underline{\text { slander }}$ \\
\hline
\end{tabular}




\section{References}

Abd-Al-Jawad, H., \& Abu-Salim, I. (1987). Slips of the tongue in Arabic and their theoretical implications. Language Sciences, 9, 14-171.

Barakai, M. (1980). Aphasic evidence for lexical and phonological representation. Afroasiatic Linguistics, 7, 3-25.

Bentin, S., \& Feldman, L. B. (1990). The contribution of morphological and semantic relatedness to repetition priming at short and long lags: evidence from Hebrew. Quarterly Journal of Experimental Psychology, 42A, 693-711.

Berg, T., \& Abd-El-Jawad, H. (1996). The unfolding of suprasegmental representations: a cross-linguistic perspective. Journal of Linguistics, 32, 291-324.

Bohas, G. (1997). Matrices, étymons, racines, éléments d'une théorie lexicologique du vocabulaire arabe. Orbis Supplementa, Louvain-Paris: Peeters.

Bohas, G. (1999). Pourquoi et comment se passer de la racine dans l'organisation du lexique de l'arabe. MS. University of Paris, Paris.

Bohas, G., \& Darfouf, N. (1993). Contribution à la réorganisation du lexique de l'arabe, les étymons nonordonnés. Linguistica Communicatio, 1 (2), 55-103.

Boudelaa, S., \& Marslen-Wilson, W. D. (2000). Non-concatenative morphemes in language processing: evidence from Modern Standard Arabic. Proceedings of the Workshop on Spoken Word Access Processes, 1, 23-26.

Deutsch, A., Frost, R., \& Forster, K. (1998). Verbs and nouns are organized and accessed differently in the mental lexicon: evidence from Hebrew. Journal of Experimental Psychology: Learning, Memory, and Cognition, 24, 1238-1255.

Drews, E., \& Zwitserlood, P. (1995). Morphological and orthographic similarity in visual word recognition. Journal of Experimental Psychology: Human Perception and Performance, 21, 1098-1116.

Feldman, L., \& Bentin, S. (1994). Morphological analysis of disrupted morphemes. Quarterly Journal of Experimental Psychology, 47A, 407-435.

Feldman, L., Frost, R., \& Pnini, T. (1995). Decomposing words into their constituent morphemes: evidence from English and Hebrew. Journal of Experimental Psychology: Learning, Memory, and Cognition, 21, 947-960.

Feldman, L., \& Soltano, E. (1999). Morphological priming: the role of prime duration, semantic transparency, and affix position. Brain and Language, 68, 33-49.

Ferguson, C. A. (1959). Diglossia. Word, 15, 325-340.

Forster, K. I. (1999). The microgenesis of priming effects in lexical access. Brain and Language, 68, 5-15.

Forster, K. I., Davis, C., Schoknecht, C., \& Carter, R. (1987). Masked priming with graphemically related forms: repetition or partial activation? Quarterly Journal of Experimental Psychology, 39, 211-251.

Forster, K. I., \& Taft, M. (1994). Bodies, antibodies and neighborhood-density effects in masked form priming. Journal of Experimental Psychology: Learning, Memory, and Cognition, 20, 844-863.

Forster, K. I., \& Veres, C. (1998). The prime lexicality effect: form-priming as a function of prime awareness, lexical status, and discrimination difficulty. Journal of Experimental Psychology: Learning, Memory, and Cognition, 24, 498-514.

Frost, R., \& Deutsch, A. (1998). Morphological decomposition is governed by representation of formal structure rather than co-occurrence of sub-lexical units. Abstracts of the 39th Annual Meeting of the Psychonomic Society.

Frost, R., Deutsch, A., Gilboa, O., Tannenbaum, M., \& Marslen-Wilson, W. D. (in press). Morphological priming: dissociation of phonological, semantic and morphological factors. Memory and Cognition.

Frost, R., Forster, K. I., \& Deutsch, A. (1997). What can we learn from the morphology of Hebrew? A masked priming investigation of morphological representation. Journal of Experimental Psychology: Learning, Memory, and Cognition, 23, 829-856.

Frost, R., Deutsch, A., \& Forster, K. (2000). Decomposing morphologically complex words in nonlinear morphology. Journal of Experimental Psychology: Learning, Memory, and Cognition, 26, 751-765.

Goldsmith, J. (1976). Autosegmental phonology. Unpublished doctoral dissertation, MIT, Cambridge, MA. 
Holes, C. (1995). Modern Arabic. London: Longman.

Hurwitz, S. T. H. (1966). Root determinatives in Semitic speech: a contribution to Semitic philology (reedition). New York: Academic Press.

Lieber, R. (1982). Allomorphy. Linguistic Analysis, 10, 27-52.

Marslen-Wilson, W. D. (1999). Abstractness and combination: the morphemic lexicon. In S. Garrod, \& M. J. Pickering (Eds.), Language processing (pp. 101-119). Hove: Psychology Press.

Marslen-Wilson, W. D., Tyler, L. K., Waksler, R., \& Older, L. (1994). Morphology and meaning in the English mental lexicon. Psychological Review, 101, 3-33.

Marslen-Wilson, W. D., \& Warren, P. (1994). Levels of perceptual representation and process in lexical access: words, phonemes and features. Psychological Review, 101, 653-675.

Marslen-Wilson, W. D., \& Zhou, X. (1999). Abstractness, allomorphy, and the lexical architecture. Language and Cognitive Processes, 14, 321-352.

Marslen-Wilson, W. D., Zhou, X. -L., \& Ford, M. (1996). Morphology, modality, and lexical architecture. In G. Booij, \& J. Van Mark (Eds.), Yearbook of morphology (pp. 117-134). Dordrecht: Kluwer.

McCarthy, J. J. (1979). Formal problems in Semitic phonology and morphology. Unpublished doctoral dissertation, MIT, Cambridge, MA.

McCarthy, J. J. (1981). A prosodic theory of non-concatenative morphology. Linguistic Inquiry, 12, 373418.

Meunier, F., \& Segui, J. (1999). Morphological priming effects: the role of surface frequency. Brain and Language, 68, 54-60.

Mimouni, Z., Béland, R., Danault, S., \& Idrissi, A. (1995). Similar language disorders in Arabic and French in an early bilingual aphasic patient. Brain and Language, 51, 132-134.

Orsolini, M., \& Marslen-Wilson, W. D. (1997). Universals in morphological representations: evidence from Italian. Language and Cognitive Processes, 13, 425-464.

Plaut, D., \& Gonnerman, L. M. (2000). Are non-semantic morphological effects incompatible with a distributed connectionist approach to lexical processing? Language and Cognitive Processes, 15, 445-485.

Prunet, J. F., Béland, R., \& Idrissi, A. (1998). Arabic consonantal root extraction in a deep dyslexic patient. Brain and Language, 65, 241-243.

Prunet, J. F., Béland, R., \& Idrissi, A. (in press). The mental representation of Semitic words. Linguistic Inquiry.

Rastle, K., Davis, M. H., Marslen-Wilson, W. D., \& Tyler, L. K. (2000). Morphological and semantic effects in visual word recognition: a time-course study. Language and Cognitive Processes, 15, $507-$ 537.

Ratcliffe, R. (1998). The "broken" plural problem in Arabic and comparative Semitic: allomorphy and analogy in non-concatenative morphology. Amsterdam: John Benjamins.

Rueckl, J. G., Mikolinski, M., Raveh, M., Miner, C. S., \& Mars, F. (1997). Morphological priming, fragment completion, and connectionist networks. Journal of Memory and Language, 36, 382-405.

Rueckl, J., \& Raveh, M. (1999). The influence of morphological regularities on the dynamics of a connectionist network. Brain and Language, 68, 110-117.

Seidenberg, M. (1987). Sublexical structures in visual word recognition: access units or orthographic redundancy. In M. Coltheart (Ed.), Attention and performance XII (pp. 131-154). Hillsdale, NJ: Erlbaum.

Sereno, J. A. (1991). Graphemic, associative and syntactic priming effects at brief stimulus onset asynchrony in lexical decision and naming. Journal of Experimental Psychology: Learning, Memory, and Cognition, 17, 459-477.

Spencer, A. \& Zwicky, A. (1998). The handbook of morphology. Oxford: Blackwell.

Taft, M. (1994). Interactive-activation as a framework for understanding morphological processing. Language and Cognitive Processes, 9, 271-294.

Versteegh, K. (1997). The Arabic language. Edinburgh: Edinburgh University Press. 